DOI: 10.12731/2658-6649-2019-11-3-39-53

УДК 316.62

\title{
АЛКОГОЛИЗМ КАК УГРОЗА СОЦИАЛЬНОЙ БЕЗОПАСНОСТИ НАСЕЛЕНИЯ ВОРОНЕЖСКОЙ ОБЛАСТИ
}

\section{Яковенко Н.В., Федотов В.И., Михно В.Б., Сафонова И.В.}

В условиях динамичности и неопределенности социальных процессов особую актуальность приобретают проблемы обеспечения безопасности, так как потребность в ней является базисным, мотивационным механизмом человеческой жизнедеятельности. Алкоголизм представляет собой комплекс медико-социальных патологий, которые крайне негативно влияют на нормальное функиионирование российского общества. Эта проблема существует столько же, сколько существует само человечество. Однако именно в нынешних условиях нестабильности социально-экономических процессов и явлений она приобретает особую значимость. Алкоголизм представляет собой угрозу для соииальной безопасности, так как наносит не только моральный, но сочиальный и экономический ущерб.

Цель исследования: раскрыть проблему алкоголизаџии населения Воронежской области в контексте сочиальной безопасности.

Материаль и методы. Основным методологическим подходом выступил системный, который дает возможность рассмотреть феномен алкоголизачии населения в зависимости от внешних и внутренних факторов его возникновения, а также сочиальных изменений, обусловленных им.

Результаты. Раскрыты основные тенденции, связанные с алкоголизмом в Воронежской области. Показаны динамика и тенденция заболеваемости алкоголизмом населения Воронежской области. Проведена классификация мунищипальных образований региона по «территориям риска».

Заключение. В современных условиях развития российского общества проблема сочиальной безопасности стоит очень остро. Алкоголизм выступает одной из угроз социального благополучия населения. Анализ ситуачии в Воронежской области показывает необходимость разработки ряда мероприятий региональными органами власти с иелью профилактики алкоголизачии населения с учетом негативных, деструктивных последствий и угроз для сочиальной безопасности региона. 
Ключевые слова: алкоголизм; Воронежская область; сочиальная безопасность; территории риска.

\section{ALCOHOLISM AS A THREAT TO SOCIAL SAFETY OF THE POPULATION IN THE VORONEZH REGION}

\section{Yakovenko N.V., Fedotov V.I., Mikhno V.B., Safonova I.V.}

In the conditions of dynamism and uncertainty of social processes, the issues of safety are of particular relevance, since the need for it is the basic, motivational mechanism of human life. Alcoholism is a complex of medical and social pathologies which have an extremely negative impact on the normal functioning of Russian society. This issue exists as much as humanity itself. However, it is in the present conditions of instability of socio-economic processes and phenomena that it becomes particularly important. Alcoholism is a threat to social safety, as it causes not only moral, but also social and economic damage.

The aim of study: to reveal the issue of the population alcoholization of the Voronezh region in the context of social safety.

Materials and methods. The main methodological approach was a systematic one, which makes it possible to consider the phenomenon of alcoholization of the population depending on external and internal factors of its occurrence, as well as social changes caused by it.

Results. The main trends related to alcoholism in the Voronezh region have been revealed. The dynamics and tendency of morbidity by alcoholism of the population of the Voronezh region has been shown. The classification of municipalities of the region by "territories of risk" has been carried out.

The conclusion. In modern conditions of the Russian society development the issue of social safety is very acute. Alcoholism is one of the threats to the social well-being of the population. The analysis of the situation in the Voronezh region shows the need to develop a number of measures by regional authorities to prevent alcoholization of the population, taking into account the negative, destructive consequences and threats to the social safety of the region.

Keywords: alcoholism; Voronezh region; social safety; risk areas.

\section{Введение}

Развитие современного российского общества привело к растущим деструктивным явлениям: преступности, алкоголизму, наркомании, и про- 
ституции. Все эти явления приводят к социальной напряжённости в обществе и поэтому объективно необходимо обращение к проблеме социальной безопасности. В научной литературе безопасность рассматривается как «...сложное социальное явление, многоплановое и многогранное в своих структурных составляющих и проявлениях, отражающее противоречивые интересы в отношениях различных социальных субъектов» [1-4]. Потребление алкоголя и распространение алкоголизма в России является актуальной проблемой национального масштаба, которая вносит серьезный вклад в формирование социальных угроз и рисков, а также приводит к сокращению человеческого потенциала в целом. Уровень злоупотребления алкогольными напитками и распространенность алкоголизма в Российской Федерации остаются стабильно высокими.

Цель исследования: раскрыть проблему алкоголизации населения Воронежской области в контексте социальной безопасности.

\section{Материалы и методы исследования}

Основном методологическим подходом выступил системный, который дает возможность рассмотреть феномен алкоголизации населения в зависимости от внешних и внутренних факторов его возникновения, а также социальных изменений, обусловленных им. Также теоретическую и методологическую основу исследования составили подходы ученых в следующем проблемном поле:

1) исследование категориального поля «феномена алкоголизации населения» [5-10];

2) социологическое понимание феномена алкоголизма в контексте безопасности [11, 12];

3) исследование проблемы алкогольной заболеваемости и психических расстройств [13-18].

\section{Результаты исследования и их обсуждение}

Проблема алкоголизма рассматривается как важнейшая социальная проблема, оказывающая влияние не только на человека и не только на его семью, но и на общество в целом. Общество расплачивается за высокую заболеваемость алкоголизмом в виде пропущенных рабочих дней, проблемами со здоровьем, медицинскими расходами, авариями, произошедшими по вине пьяных водителей и т.д. Алкоголизм как социальное явление рассматривается с различных точек зрения в попытке объяснить его этиологию или последствия. Конечно же прерогативой выступает медицинское 
объяснение, согласно которой алкоголизм является заболеванием и его нужно лечить с помощью медицинских средств. Однако этот подход имеет свои ограничения, и жизнеспособной альтернативной перспективой, основанной на иной этиологии и иной методологии решения этой проблемы, является социологическая перспектива.

Согласно научному трактованию: « ..Алкоголизм - это вид химической аддикции, формирующей физическую и психологическую зависимость от алкоголя, вызывающего саморазрушительное и социально деструктивное поведение человека и групп населения, угрожающего жизни, здоровью, социальному статусу индивидуума, благополучию его семьи. Алкогольная зависимость являясь полифакторной, определяется наследственно-биологическими, социально-экономическими, культурными, психолого-педагогическими причинами с негативными последствиями для биопсихо-социального здоровья человека и нации в ее историческом развитии» [19]. Последствия алкоголизма таковы, что он влияет не только на отдельную личность, он оказывает влияние на содержание духовно-нравственных ценностей, формирование образа жизни человека, на систему взаимоотношений с окружающими в процессе общения. И в то же время, алкоголизм оказывает воздействие на общество в целом, так как это показатель морального и физического здоровья нации, которое обусловлено разными факторами: социально-экономическими, политическими и психологическими. По данным ВОЗ в результате употребления алкоголя во всем мире ежегодно умирает 3,3 млн. чел. (5,9\% всех случаев смерти). Злоупотребление алкоголем является одно из причин более чем 200 нарушений состояния здоровья, обусловленных болезнями и травмами [19].

В среднем на 1 человека в России приходится 15-18 литров чистого спирта в год. Доля населения, которое потребляет алкоголь составляет $70 \%$, при этом наиболее активными потребителями является население в трудоспособном возрасте (24-39 лет). Согласно данным Росстата [20] алкоголизм значительно молодеет, поскольку впервые подростки пробует алкогольные напитки в возрасте 14-15 лет. По официальным данным за 2017 г. количество подростков, употребляющих алкоголь составило 20,8\% на 100 тыс. чел. Однако, чтобы получить достоверную картину, эту цифру необходимо умножить минимум в 5 раз. Следует отметить и тот факт, что при алкоголизме наносится не только социальный, но и экономический ущерб экономике России, обусловленный целым рядом последствий: разводы, автодорожные происшествия, преступления, экономические убытки, за- 
траты на медицинскую и социальную помощь больным. По данным ВОЗ расходы, связанные с алкоголизмом, составляют в среднем 2-5\% ВВП [19].

Количество больных алкоголизмом в России составляет более 5 млн. чел. (3,4\% от всего населения) [20], причем на учёте состоит всего $1,7 \%$ чел. (рис. 1). По данным Всемирной организации здравоохранения ежегодно в мире фиксируется более 3 млн. смертей, обусловленных злоупотреблением алкогольной продукцией. В 2017 г. произошло резкое снижение количества населения которым был поставлен диагноз «алкоголизм» впервые (всего 42 случая на 100 тыс. чел.), что на 55\% меньше, чем в 2005 г., по отношению к 2016 г. снижение составило 11\%. Заболеваемость алкогольными психозами (так называемая белая горячка) демонстрирует такую же тенденцию: В 2017 г. количество впервые поставленных диагнозов уменьшилось на 74\% (по сравнению с 2005 г., 13,3 случая на 100000 чел.), в 2016 г. - на 23,2\%.

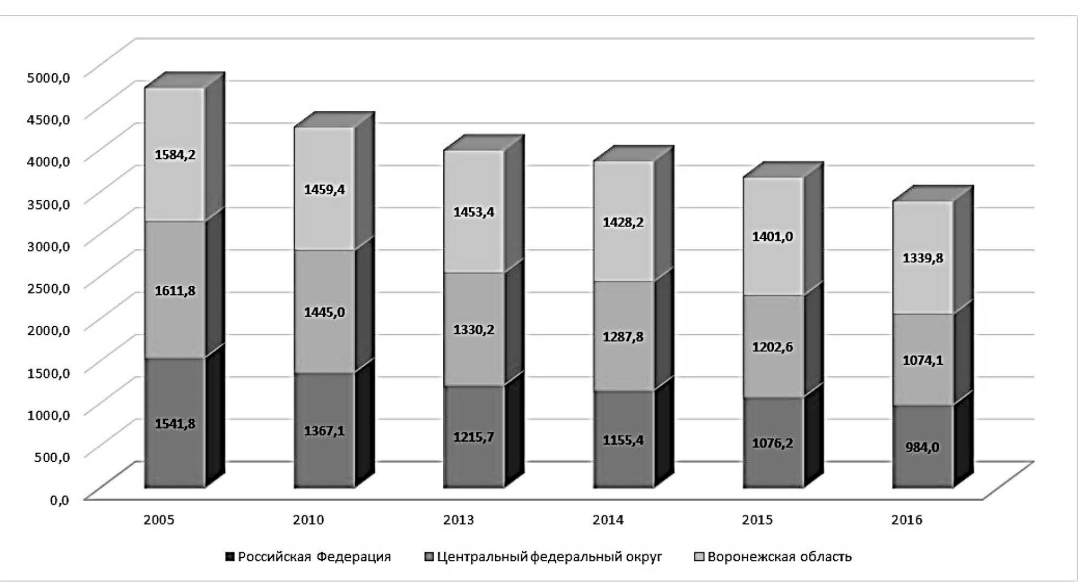

Рис. 1. Заболеваемость алкоголизмом населения (на 100000 чел.)

Воронежская область не является исключением из российских регионов, и данная проблема выступает и для нее очень остро. Ежегодно более $50 \%$ муниципальных образований области формируют «территории риска» по заболеваемости населения алкоголизмом. В 2017 г. «неблагополучными» территориями выступили следующие муниципальные районы: Бобровский, Верхнемамонский, Верхнехавский, Воробъевский, Каменский, Кантемировский, Каширский, Лискинский, Ольховатский, Острогожский, Панинский, Поворинский, Подгоренский, Семилукский, Хохольский, Эртильский и Борисоглебский городской округ (рис. 2, 3) [21]. 


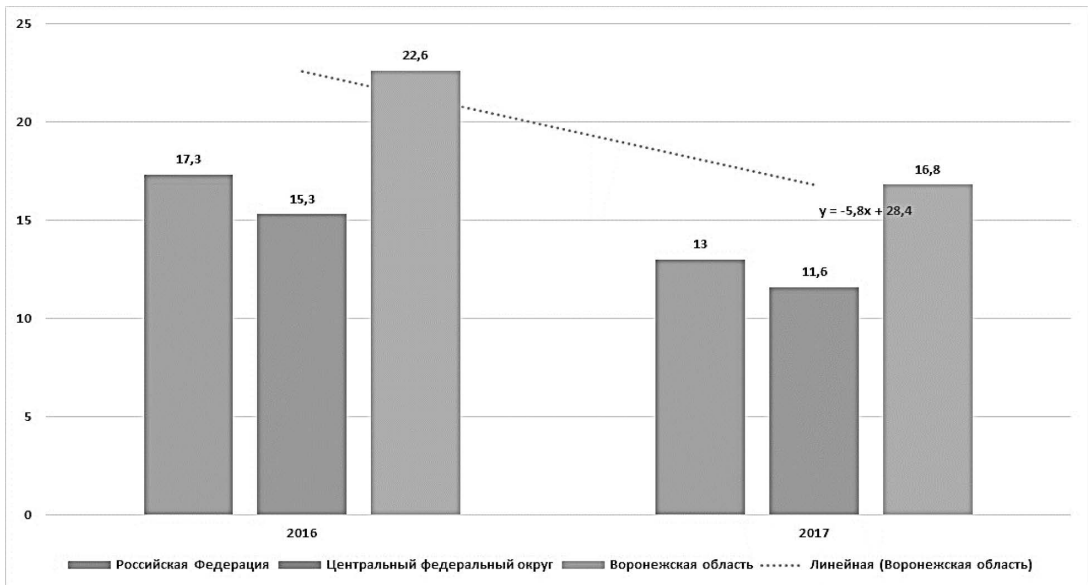

Рис. 2. Психологические расстройства, связанные с употреблением алкоголя (на 10000 чел.)

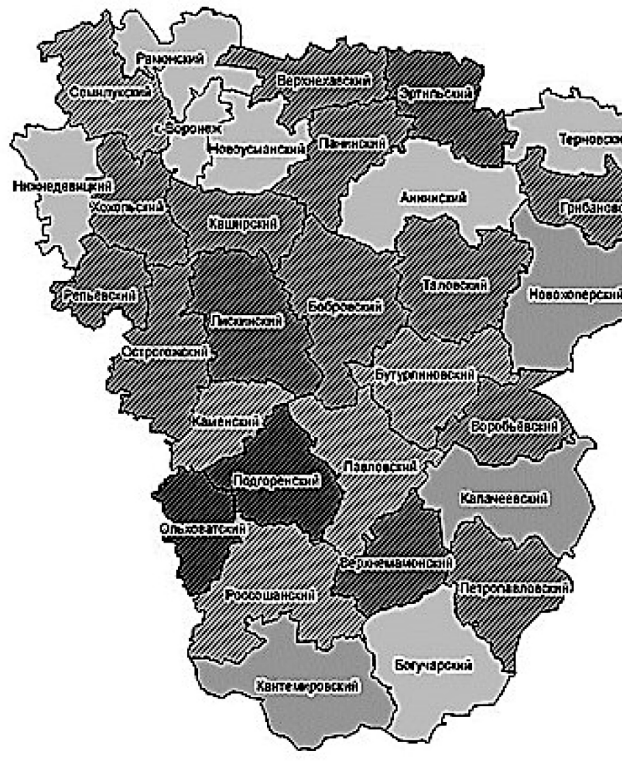

Ұсловные обозначенкя

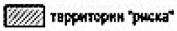

Показатель на 100000 населенкя

$\square 31,38 \cdot 54,29$

$54,30 \cdot 85,92$

$85,83 \cdot 146,86$

$145,87-216,48$

$216,49 \cdot 257,42$

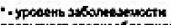

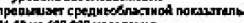

Рис. 3. Заболеваемость алкоголизмом населения Воронежской области (территории «риска», 2017 г.) 
За последние три года на территории Воронежской области зарегистрированы 2240 случаев острых отравлений спиртосодержащей продукцией, тогда как в 2015 г. - 827, 2016 г. - 742, 2017 г. - 671, в том числе 1318 случаев (58,8\%) - с летальным исходом (для сравнения: 2015 г. - 494, 2016 г. 464, 2017 г. - 360) (рис. 4, 5).

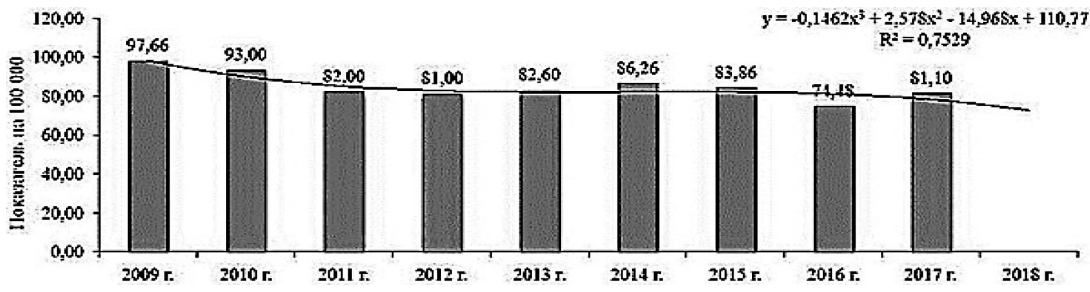

Рис. 4. Динамика и тенденция заболеваемости алкоголизмом населения Воронежской области (на 100 000)

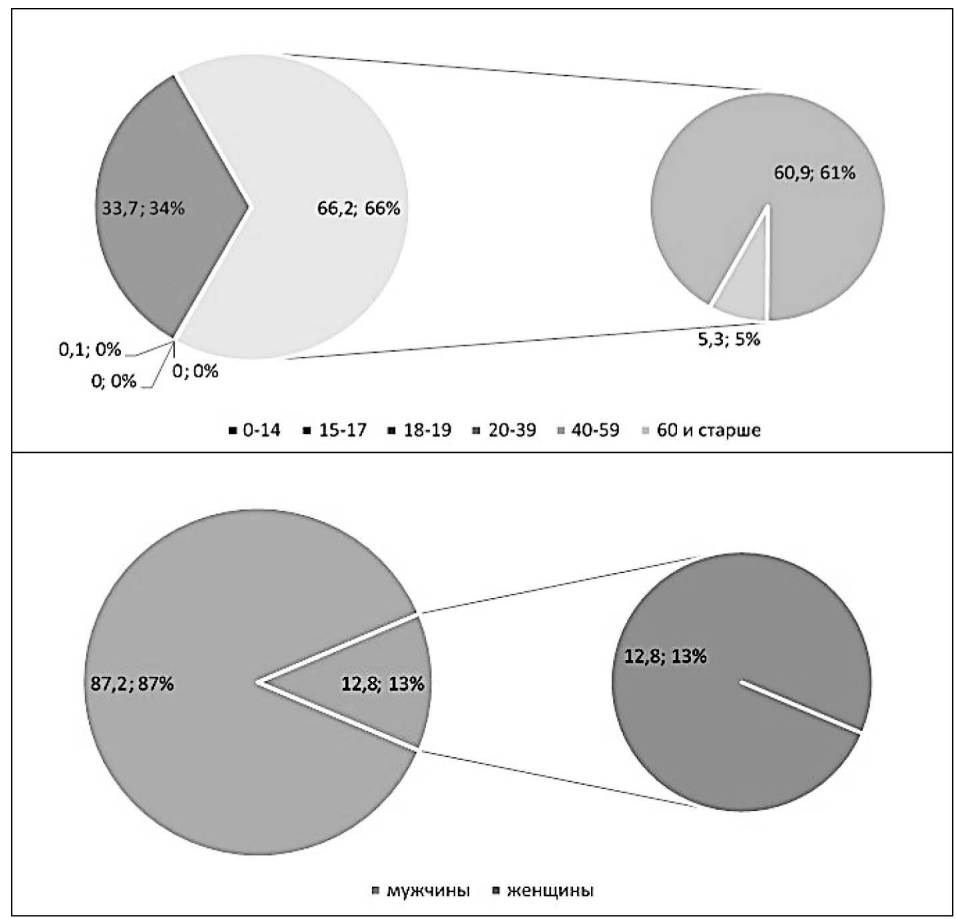

Рис. 5. Половозрастная структура заболеваемости населения алкоголизмом (2017 г.), \% 
В половозрастной структуре заболеваемости населения алкоголизмом $60,9 \%$ составляет население в возрасте 40-59 лет, и в большей мере - это мужское население. Женщины составляют всего 12,8\% (рис. 3). Также значительную долю в структуре заболеваемости алкоголизмом составляет население в возрасте 20-39 лет - 33,7\%.

Ситуация складывается таким катастрофическим образом, что на территории Воронежской области можно выделить так называемые «территории риска»: Ольховатский, Подгоренский, Верхнемамонский районы - наиболее кризисные. Также можно выделить и муниципальные районы, где наблюдается критическая ситуация, обусловленная наличием большого количества населения с алкогольными психозами («территории риска»): Подгоренский, Острогожский, Нижнедевицкий, Хохольский и Рамонский.

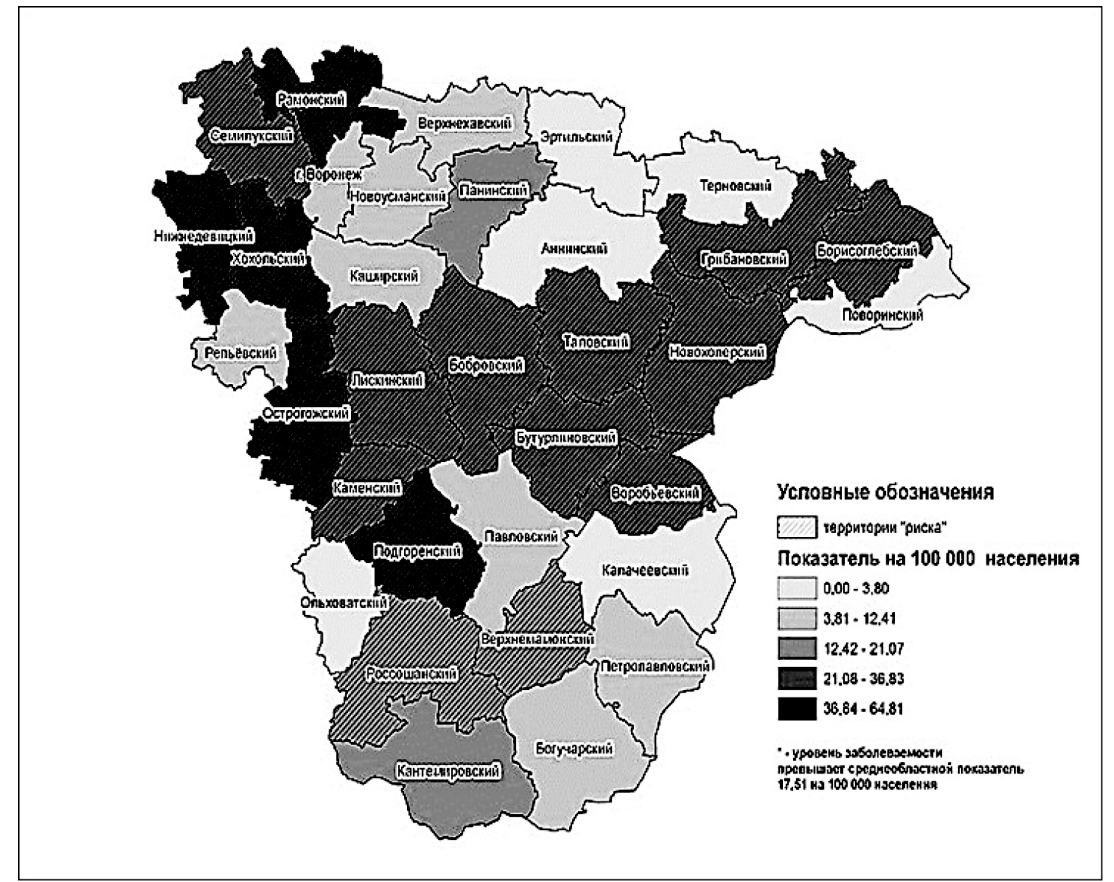

Рис. 6. Заболеваемость алкогольными психозами населения Воронежской области (территории «риска», 2017 г.)

В регионе можно выделить муниципальные районы, представляющие собой «территории риска». Основным критерием отнесения к этим террито- 
риям является впервые зарегистрированные случаи с вредными последствиями употребления алкоголя среди населения. К этим территориям относятся Верхнехавский, Эртильский и Подгоренский муниципальные районы (рис. 6).

Основными причинами такой неблагоприятной ситуации в выявленных неблагополучных районах являются закрытие производственных (градообразующих) предприятий, что способствовало сокращению рабочих мест, и как следствие, резкому ухудшению социально-экономическое благосостояния и качеству жизни населения [3, 4]. Кроме этого, немаловажным фактором является обеспеченность медицинскими учреждениями и медицинским персоналом, а потому и низкий уровень реабилитационных мероприятий в медицинских организациях.

\section{Заключение}

Алкоголизация как социальная проблема, свойственная для всех регионов Российской Федерации, отражает общее неблагополучие в сфере социальной безопасности. В контексте угрозы для социальной безопасности, алкоголизация негативно влияет на социально-демографические, а также нравственно-духовные основы развития общества, ведет к ухудшению наиболее важных показателей жизнедеятельности. На уровне Воронежской области, исходя из положений действующего федерального законодательства, представляется целесообразным принятие следующих мер (рис. 7).

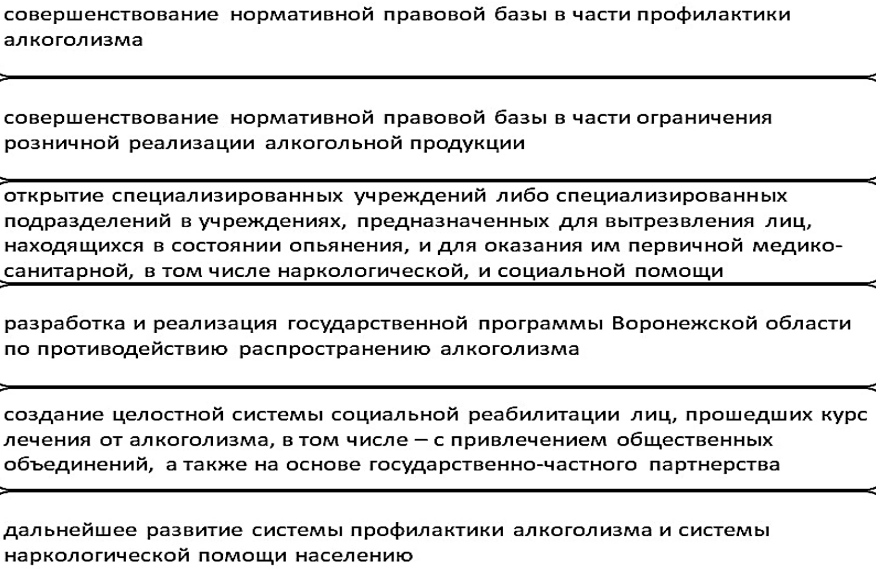

Рис. 7. Меры по предупреждению и профилактики алкоголизма в Воронежской области 
Результаты проведенного анализа и классификации муниципальных районов Воронежской области по проблемам алкоголизации (потребление, смертность и алкогольные психозы) должны учитываться органами управления, департаментом здравоохранения и наркологической службой региона для реализации мероприятий в области повышения качества и эффективности медицинского обслуживания больным алкоголизмом.

Информация о конфликте интересов. Авторы заявляют об отсутствии конфликта интересов.

\section{Список литературы}

1. Чмыхало А. Ю. Социальная безопасность: Учебное пособие. Томск: Издво ТПУ, 2007. 168 с.

2. Барденштейн Л.М. Алкоголизм и наркомания: вопрос национальной безопасности // Российский медицинский журнал. 2013. № 4. С. 3.

3. Яковенко Н.В. Качество атмосферного воздуха как составляющая качества среды обитания Ивановской области/ Н.В. Яковенко, Д.С. Марков // Современные исследования социальных проблем. 2012. № 11. С. 77.

4. Яковенко Н.В. Факторы окружающей среды в формировании здоровья населения Ивановской области (атмосферный воздух) / Н.В. Яковенко, Д.С. Марков, А.А. Молодцева, Е.П. Туркина //Современные проблемы науки и образования. 2013. № 5. С. 461-469.

5. Jayasekara H., English D.R., Room R., MacInnis R.J. Alcohol consumption over time and risk of death: a systematic review and meta-analysis // Am. J. Epidemiol, 2014, vol. 179, no. 9, pp. 1049-1059.

6. Roerecke M., Rehm J. Cause-specifi c mortalityrisk in alcohol use disorder treatment patients: a systematic review and meta-analysis // Int. J. Epidemiol, 2014, vol. 43, no.4, pp. 1314-1327.

7. Wedegaertner F., Geyer S., Arnhold-Kerri S., Sittaro N.A., te Wildt B. Alcohol use disorder-related sick leaveand mortality: a cohort study // Addict. Sci. Clin. Pract, 2013, vol.30, no. 8.3, pp. 27-35.

8. Montes-Santiago J., Roseiro-Sordo M. Alcohol abuse numbers in Spain: nearly 420,000 deaths in current century // Revista Clinica Espanola, 2018, vol. 218, no 7, pp. 386-388.

9. Rodríguez-López J., Gurriarán X., Calvo R., Arrojo M., Costas J., Flórez G., Estévez V., Gómez-Trigo J., Longo M.J., Álvarez S., Blanco V., Pereiro C., Carrera I., Páramo M.J., López N., García A., Fernández J.M., Fariñas E., Sáiz P., Vázquez F.L. et al. Genome wide analysis of rare copy number variations in 
alcohol abuse or dependence // Journal of Psychiatric Research, 2018, vol. 103, pp. 212-218.

10. Radaev V. Impact of a new alcohol policy on homemade alcohol consumption and sales in Russia // Alcohol and alcoholism, 2015, vol. 3, pp. 365-372.

11. Pons J., Buelga S. Factors associated with youth alcohol consumption: a review from a psychosocial and ecological perspective // Psychosocial Intervention. 2011. vol. 20, no. 1, pp. 75-94.

12. Martín J.L.V., Galán I., González M.J. Methodological issues in the measurement of alcohol consumption: the importance of drinking patterns // Revista Espanola de Salud Publica, 2014,vol. 88. no. 4. pp. 433-446.

13. Ассоциация генов подверженности к алкоголизму, шизофрении и болезни Альцгеймера с психодиагностическими признаками в популяции русских/ Марусин А.В., Корнетов А.Н., Сваровская М.Г., Вагайцева К.В., Павленюк Е.С., Степанов В.А. // Бюллетень сибирской медицины. 2016. Т. 15. № 5. C. 83-96.

14. Шелыгин К.В. Заболеваемость алкогольными психозами, смертность от отравлений алкоголем и патологии печени в России в зависимости от финансовой доступности алкоголя // Журнал неврологии и психиатрии им. С.С. Корсакова. 2015. Т. 115. № 8. С. 76-78.

15. Вязьмин А.М., Мордовский Э.А., Соловьев А.Г. Смертность от состояний, связанных с употреблением алкоголя//Проблемы социальной гигиены, здравоохранения и истории медицины. 2013. № 2. С. 13-16.

16. Горный Б.Э., Калинина А.М., Бунова А.С. Потребление алкоголя и смертность от алкоголь-обусловленных состояний в отдельных странах европейского региона //Наркология. 2018. Т. 17. № 10. С. 75-79.

17. Морфологические изменения некоторых субстанций головного мозга при различных формах алкогольной интоксикации/Савин А. А., Павлов А. Л., Павлова А.З., Богомолов Д.В., Ларев 3.В.// Наркология. 2018. Т.2. С. 29-38.

18. Особенности алкоголизма, сформировавшегося на фоне расстройства личности: клинический случай/Пронин Р.А., Дюжев Д.В., Аблова В.В., Винникова М.А. // Наркология. 2018. Т.2. С. 61-71.

19. Глобальная стратегия сокращения вредного употребления алкоголя. ВОЗ. URL.: https://apps.who.int/iris/bitstream/handle/1rus.pdf(дата обращения: 1.02.2019).

20. О состоянии санитарно-эпидемиологического благополучия населения в Российской Федерации в 2017 году. Государственный доклад. М.: Федеральная служба по надзору в сфере защиты прав потребителей и благополучия человека, 2018. 268 с. 
21. Информационно-справочный материал «Здоровье населения» (показатели и данные регионального информационного фонда социально-гигиенического мониторинга за 2015-2017 годы). Воронеж: Управление Роспотребнадзора по Воронежской области. ФБУЗ «Центр гигиены и эпидемиологии в Воронежской области», 2018. 105 с.

\section{References}

1. Chmyhalo A. Yu. Social 'naya bezopasnost': uchebnoe posobie [Social safety: a textbook]. Tomsk: Publishing house TPU, 2007, 168 p.

2. Bardenshtejn L.M. Alkogolizm i narkomaniya: vopros nacional'noj bezopasnosti [Alcoholism and drug addiction: a matter of national safety]. Rossijskij medicinskij zhurnal, 2013, no. 4. P. 3.

3. Yakovenko N.V., Markov D.S. Kachestvo atmosfernogo vozduha kak sostavlyayushchaya kachestva sredy obitaniya Ivanovskoj oblasti. [Atmospheric air quality as a component of habitat quality in the Ivanovo region]. Sovremennye issledovaniya social'nyh problem. 2012. № 11. P. 77.

4. Yakovenko N.V., Markov D.S., Molodceva A.A., Turkina E.P. Faktory okruzhayushchej sredy v formirovanii zdorov'ya naseleniya Ivanovskoj oblasti (atmosfernyj vozduh) [Environmental factors in the formation of health of the population in the Ivanovo region (atmospheric air)]. Sovremennye problemy nauki i obrazovaniya, 2013, no. 5, pp. 461-469.

5. Jayasekara H., English D.R., Room R., MacInnis R.J. Alcohol consumption over time and risk of death: a systematic review and meta-analysis. Am. J. Epidemiol, 2014, vol. 179, no. 9, pp. 1049-1059.

6. Roerecke M., Rehm J. Cause-specifi c mortalityrisk in alcohol use disorder treatment patients: a systematic review and meta-analysis. Int. J. Epidemiol, 2014, vol. 43, no.4. pp. 1314-1327.

7. Wedegaertner F., Geyer S., Arnhold-Kerri S., Sittaro N.A., te Wildt B. Alcohol use disorder-related sick leaveand mortality: a cohort study. Addict. Sci. Clin. Pract, 2013, vol.30, no. 8.3, pp. 27-35.

8. Montes-Santiago J., Roseiro-Sordo M. Alcohol abuse numbers in Spain: nearly 420,000 deaths in current century. Revista Clinica Espanola, 2018, vol. 218 , no 7, pp. 386-388.

9. Rodríguez-López J., Gurriarán X., Calvo R., Arrojo M., Costas J., Flórez G., Estévez V., Gómez-Trigo J., Longo M.J., Álvarez S., Blanco V., Pereiro C., Carrera I., Páramo M.J., López N., García A., Fernández J.M., Fariñas E., Sáiz P., Vázquez F.L. et al. Genome wide analysis of rare copy number variations in alcohol abuse or dependence. Journal of Psychiatric Research, 2018, vol. 103, pp. 212-218. 
10. Radaev V. Impact of a new alcohol policy on homemade alcohol consumption and sales in Russia. Alcohol and alcoholism, 2015, vol. 3, pp. 365-372.

11. Pons J., Buelga S. Factors associated with youth alcohol consumption: a review from a psychosocial and ecological perspective. Psychosocial Intervention, 2011, vol. 20, no. 1, pp. 75-94.

12. Martín J.L.V., Galán I., González M.J. Methodological issues in the measurement of alcohol consumption: the importance of drinking patterns. Revista Espanola de Salud Publica, 2014, vol. 88. no. 4. pp. 433-446.

13. Marusin A.V., Kornetov A.N., Svarovskaya M.G., Vagajceva K.V., Pavlenyuk E.S., Stepanov V.A. Associaciya genov podverzhennosti k alkogolizmu, shizofrenii i bolezni Al'cgejmera s psihodiagnosticheskimi priznakami v populyacii russkih [Association of genes of susceptibility to alcoholism, schizophrenia and Alzheimer's disease with psychodiagnostic signs in Russian population]. Byulleten' sibirskoj mediciny, 2016. vol. 15, no.№ 5, pp. 83-96.

14. Shelygin K.V. Zabolevaemost' alkogol'nymi psihozami, smertnost' ot otravlenij alkogolem i patologii pecheni $\mathrm{v}$ rossii $\mathrm{v}$ zavisimosti ot finansovoj dostupnosti alkogolya [Morbidity of alcoholic psychoses, mortality from alcohol poisoning and liver pathology in Russia depending on the financial availability of alcohol]. Zhurnal nevrologii i psihiatrii im. C.C. Korsakova, 2015, vol. 115, no. 8, pp. 76-78.

15. Vyaz'min A.M., Mordovskij Eh.A., Solov'ev A.G. Smertnost' ot sostoyanij, svyazannyh s upotrebleniem alkogolya [Mortality from alcohol-related conditions]. Problemy social'noj gigieny, zdravoohraneniya i istorii mediciny, 2013, no. 2, pp. 13-16.

16. Gornyj B.Eh., Kalinina A.M., Bunova A.S. Potreblenie alkogolya i smertnost' ot alkogol'-obuslovlennyh sostoyanij v otdel'nyh stranah evropejskogo regiona [Alcohol consumption and alcohol-related mortality in selected countries of the European region]. Narkologiya, 2018, vol. 17, no. 10, pp. 75-79.

17. Savin A.A., Pavlov A.L., Pavlova A.Z., Bogomolov D.V., Larev Z.V. Morfologicheskie izmeneniya nekotoryh substancij golovnogo mozga pri razlichnyh formah alkogol'noj intoksikacii [Morphological changes in some substances of the brain in various forms of alcohol intoxication]. Narkologiya, 2018, vol. 2, pp. 29-38.

18. Pronin R.A., Dyuzhev D.V., Ablova V.V., Vinnikova M.A. Osobennosti alkogolizma, sformirovavshegosya na fone rasstrojstva lichnosti: klinicheskij sluchaj [Features of alcoholism, formed on the background of personality disorder: clinical case]. Narkologiya, 2018, vol. 2, pp. 61-71. 
19. Informacionno-spravochnyj material «Zdorov’e naseleniya» (pokazateli i dannye regional'nogo informacionnogo fonda social'no-gigienicheskogo monitoringa za 2015-2017 gody) [Information and reference material "Public health" (indicators and data of the regional information Fund of social and hygienic monitoring for 2015-2017)]. Voronezh: Office of Rospotrebnadzor in the Voronezh region. Centre of hygiene and epidemiology in the Voronezh region, 2018, $105 \mathrm{p}$.

20. Global'naya strategiya sokrashcheniya vrednogo upotrebleniya alkogolya [A global strategy to reduce the harmful use of alcohol. WHO]. World Health Organization. https://apps.who.int/iris/bitstream/handle/1rus.pdf (accessed February 1, 2019).

21. O sostoyanii sanitarno-ehpidemiologicheskogo blagopoluchiya naseleniya $v$ Rossijskoj Federacii v 2017 godu. Gosudarstvennyj doklad. [On the state of sanitary and epidemiological welfare of the population in the Russian Federation in 2017. State report]. Moscow: The Federal Service for Supervision of Consumer Rights Protection and Human Well-Being, 2018, 268 p.

\section{ДАННЫЕ ОБ АВТОРАХ}

Наталия Владимировна Яковенко, доктор географических наук, профессор, заведующий кафедрой социально-экономической географии и регионоведения

Воронежский государственный университет ул. Хользунова, 40, г. Воронеж, Российская Федерация n.v.yakovenko71@gmail.com

Владимир Иванович Федотов, доктор географических наук, профессор, кафедры рекреационной географии, страноведения и туризма Воронежский государственный университет ул. Хользунова, 40, г. Воронеж, Российская Федерация

Владимир Борисович Михно, доктор географических наук, профессор кафедры физической географии и оптимизации ландшафта Воронежский государственный университет ул. Хользунова, 40, г. Воронеж, Российская Федераџия

Сафонова Ирина Вячеславовна, преподаватель кафедры социальноэкономической географии и регионоведения Воронежский государственный университет ул. Хользунова, 40, г. Воронеж, Российская Федерация 


\section{DATA ABOUT THE AUTHORS}

Nataliya Vladimirovna Yakovenko, Doctor of Geography, Professor, Head of the Department of Social and Economic Geography and Regional Studies, Faculty of Geography, Geoecology and Tourism

Voronezh State University

40, Kholzunova str., 40, Voronezh, Russian Federation

n.v.yakovenko71@gmail.com

SPIN-code: 2518-1401

ORCID: 0000-0003-4203-0040

ResearcherID: C-9545-2015

Author ID: 57093623400

Vladimir Ivanovitch Fedotov, Doctor of Geography, Professor, Department of Recreational Geography, Country Studies and Tourism Voronezh State University

40, Kholzunova str., 40, Voronezh, Russian Federation

SPIN-code: $7868-4432$

ORCID: 0000-0002-2753-4702

Vladimir Borisovitch Mikhno, Doctor of Geography, Professor of the Department of Physical Geography and Landscape Optimization Voronezh State University 40, Kholzunova str., 40, Voronezh, Russian Federation SPIN-code: $5348-1602$

ORCID: 0000-0002-3385-5799

Safonova Irina Vyacheslavovna, Teacher of Social and Economic Geography and Regional Studies, Faculty of Geography, Geoecology and Tourism Voronezh State University

40, Kholzunova str., 40, Voronezh, Russian Federation

SPIN-code: 7403-6890

ORCID: 0000-0003-2782-0378 